\title{
Die veld van gewone taal in Afrikaans oopgeskryf
}

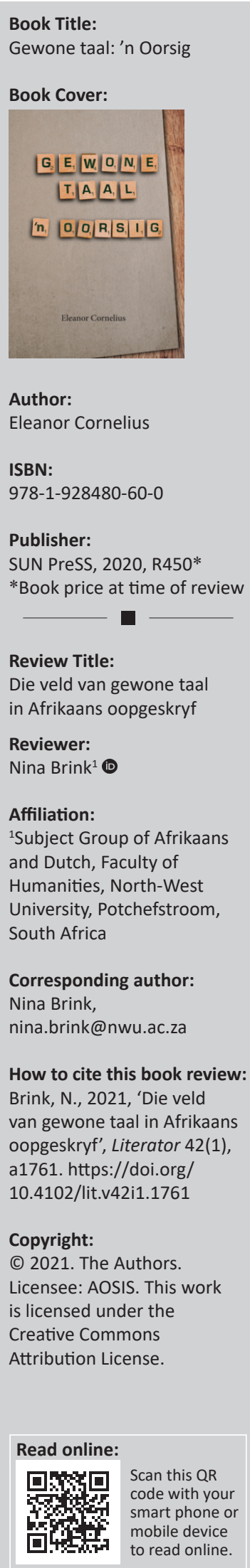

Alhoewel Cornelius tereg meld dat dit geen maklike taak is om die konsep van gewone taal te omskryf nie, kan dit losweg gedefinieer word as die vereenvoudiging van komplekse sinstrukture en ander elemente van ' $n$ teks om dit meer toeganklik vir die 'gewone' taalgebruiker, oftewel die lekeleser, te maak (Schriver 1991:1). Dit is derhalwe'n belangrike veld wat baie praktiese waarde vir gewone taalgebruikers inhou deurdat komplekse tekste (veral tekste met regsimplikasies) oorgeskryf of herformuleer moet word ten einde die verstaanbaarheid daarvan te verhoog. In hierdie lig beskou, is dit eintlik verstommend dat hierdie werk van Cornelius die eerste omvattende bron in Afrikaans is wat uitsluitlik op die veld van gewone taal fokus.

Die boek is in drie dele verdeel. In die eerste deel word daar gekyk na die konsep van gewone taal en meer spesifiek na aspekte soos waarna gewone taal verwys, die verhouding tussen gewone taal, vertaling en teksvereenvoudiging, hoe hierdie veld ontwikkel het en voordele van en kritiek op die gebruik van gewone taal. 'n Kontrolelys vir gewone taal en ontwerp word ook verskaf. In die tweede deel, getiteld 'Bronne van kompleksiteit', word daar meer gedetailleerd gekyk na aspekte soos leesprosesse, leesprobleme en toetsmetodes vir die bepaling van tekskwaliteit en leesbaarheid, wat kompleksiteit op woord-, sins- en teksvlak behels en hoe verhoogde leesbaarheid deur goeie dokumentontwerp en uitleg bewerkstellig kan word. Die derde deel is 'n kykie na hoe die gebruik van gewone taal in verskillende domeine prakties toegepas kan word. Hier word praktiese voorbeelde verskaf van tekste se voorweergawes en dan ook die naweergawes nadat dit in gewone taal herskryf is. Voorbeelde van voor- en naweergawes op woordvlak, sinsvlak, makrostrukturele teksvlak en tipografiese vlak word verskaf, en daar is ook 'n voorbeeld van 'n koopkragkaart-ooreenkoms. Die derde deel, en die boek as geheel, word afgesluit met gevolgtrekkings en aanbevelings rakende moontlike temas wat deur voornemende nagraadse studente op honneurs-, magister- of doktorale vlak ondersoek kan word.

Cornelius toon in hoofstuk vier aan watter voordele gewone taal op verskillende vlakke vir verskillende mense inhou en fokus ook spesifiek op hoe kostedoeltreffend en tydbesparend dit kan wees. Een van die vele doelstellings van die gebruik van gewone taal is ook om die verbruiker wat ' $n$ lekeleser is, te beskerm. Soos Cornelius verduidelik, het die inwerkingtreding van die Nasionale Kredietwet 34 van 2005 en die Wet op Verbruikersbeskerming 68 van 2008 dit veral genoodsaak dat taalpraktisyns in gewone taal opgelei moet word, aangesien dit nou 'n basiese reg is dat gebruikers inligting in gewone en verstaanbare taal moet kan ontvang. Cornelius se boek is derhalwe baanbrekerswerk in hierdie verband, aangesien die gewonetaalpraktisyn, wat veral in Afrikaans werk, nou in een omvattende en toeganklike bron antwoorde op sekere vrae kan ontvang en ook verwys word na ander bronne waar daar verder opgelees kan word oor gewone taal.

Hierdie werk is egter nie net van toepassing op gewonetaalpraktisyns nie, en is myns insiens ' $n$ boek wat hoort op die rak van enige vertaler, teksredigeerder, taalkundestudent wat in taalpraktyk opgelei word en selfs toegepaste en beskrywende taalkundige wat in ander velde werk. Dit is wel 'n akademiese bron en is daarom nie noodwendig vir die lekeleser geskryf nie, maar eerder met die doelstelling om leiding te verskaf aan die taalpraktisyn wat tekste vir die lekeleser toeganklik moet maak.

Daar is slegs 'n paar punte van kritiek waarvan die eerste is dat die deurlopende toepassing op veral regstekste of tekste wat regsimplikasies het, nie noodwendig baie interessant is vir alle lesers nie. Cornelius maak dit wel duidelik dat hierdie tipe tekste as voorbeelde gekies word omdat dit juis gewoonlik sulke tipe tekste is wat in gewone taal herskryf moet word. Sy verskaf ook in hoofstuk tien 'n paar voorbeelde van ander tipes tekste in ander domeine, alhoewel dit steeds minimaal is. ' $n$ Ander punt van kritiek is dat die titel van hoofstuk drie sê dat daar na die ontwikkeling van gewone taal in die Suid-Afrikaanse (plaaslike) konteks ook gekyk word, maar die hoofstuk sluit af met 'n oorsig oor gewone taal in Suid-Asië, sonder dat daar by die Suid-Afrikaanse konteks uitgekom word. Die laaste punt van kritiek is dat daar nie vir elke 
hoofstuk 'n slotsom of samevatting verskaf word nie en dat dit tog iets is wat ' $n$ mens mis, aangesien die hoofstukke baie inligting bevat.

Ten spyte van die paar punte van kritiek, is hierdie boek werklik 'n bron wat 'n besliste leemte in die huidige Afrikaanse literatuur vul. Cornelius behandel ook vele aspekte wat tot nuwe insigte vir die (onervare) gewonetaalpraktisyn en selfs vir die teksredigeerder of ander taalkundige kan lei. 'n Ander voordeel, veral vir die ontluikende navorser, is ook die afdeling waar Cornelius aandui in watter velde binne gewone taal daar nog ruimte is vir toekomstige navorsing. Die boek is goed gestruktureer en die uiteensetting van gewone taal word op 'n eenvoudige en toeganklike wyse aangebied.

\section{Literatuurverwysing}

Schriver, K.A., 1991, Technical Report No. 46: Plain language for expert or lay audiences: Designing text using protocol-aided revision, Centre for the Study of Writing, Berkeley, CA. 